Article

\title{
Optimal Switching Table-Based Sliding Mode Control of an Energy Recovery Li-Ion Power Accumulator Battery Pack Testing System
}

\section{Bo Long ${ }^{1}$, Ji Hyoung Ryu ${ }^{2}$ and Kil To Chong ${ }^{2, *}$}

1 School of Mechanical, Electronic, and Industrial Engineering, University of Electronic Science and Technology of China, Chengdu 611731, China; E-Mail: longbo1978@gmail.com

2 Departments of Electronics \& Information Engineering, Chonbuk National University, Jeonju 567, Korea; E-Mail: lovesure@hanmail.net

* Author to whom correspondence should be addressed; E-Mail: kitchong@chonbuk.ac.kr; Tel.: +82-63-270-2478; Fax: +82-63-270-2394.

Received: 14 August 2013; in revised form: 29 September 2013 / Accepted: 10 October 2013 / Published: 14 October 2013

\begin{abstract}
The main objective of the present work is to apply a sliding mode controller (SMC) to medium voltage and high power output energy recovery Li-ion power accumulator battery pack testing systems (ERLPABTSs), which are composed of a three-level neutral-point-clamped (NPC) three-phase voltage source inverter (VSI) and a two-level buck-boost converter without an isolating transformer. An inner current decoupled control scheme for the aforementioned system is proposed and two sliding mode planes for active and reactive current control are designed based on the control scheme. An optimized switching table for current convergence is used according to the error sign of the equivalent input voltage and feedback voltage. The proposed ERLPABTS could be used to integrate discharging energy into the power grid when performing high accuracy current testing. The active and reactive power references for the grid-connected inverter are determined based on the discharging energy from the DC-DC converter. Simulations and experiments on a laboratory hardware platform using a $175 \mathrm{~kW}$ insulated gate bipolar transistor (IGBT)-based ERLPABTS have been implemented and verified, and the performance is found satisfactory and superior to conventional ERLPABPTS.
\end{abstract}


Keywords: energy recovery Li-ion power accumulator battery pack testing system (ERPALBPTS); neutral point clamped-voltage source inverter (NPC-VSI); sliding mode control (SMC)

\section{Introduction}

Energy has become one of the most important parts of our lives and, due to its widespread use and effects, there is a need to create methods of conserving it, particularly to prevent further air pollution. Many countries have invested heavily in developing electric vehicles (EVs), which usually contain three parts: a driving motor, a power transmission system, and a power supply system. The first two technologies have been heavily investigated and are becoming increasingly reliable. However, the power battery pack, which influences the driving mileage, requires further optimization before electric vehicles can be commercialized successfully. The power battery pack testing system is used to evaluate the performance of power accumulator batteries, and it plays an important role in choosing and comparing batteries for EVs. There has been considerable research on battery pack testing systems [1-10]. A bi-directional energy flow power circuit topology combined with the control scheme used for power accumulator battery pack testing system (PABPTS) was designed to reduce the energy required for discharge test experiments and was described in [11]. This technology can integrate discharging energy of Li-ion battery with the power grid, and is called an energy recovery power accumulator battery pack testing system (ERPABPTS).

Most conventional ERLPABTSs featuring bi-directional two-level voltage source converters for DC-AC transformation have suffered from large switching stress and wastage. This is because conventional ERLPABTSs have the drawbacks of high total harmonic distortion, power transistors in the two-level converter when used for medium voltage (e.g., 900-1000 V), and high power output (e.g., $250 \mathrm{~kW}$ ). Voltage rating requirements are much higher for two-level voltage source converters. The neutral-point-clamped (NPC) PWM inverter, which was first described by Nabae and Akira [12] in 1981, has emerged as a solution for working with higher voltage levels. The commutation of the switches permits the addition of capacitor voltages, which can reach high voltages at the output, while the power semiconductors only need to withstand reduced voltages [13]. The following attractive features could be achieved if NPC-based three-level converters could be integrated into the power circuit topology of ERPBTSs: (1) extremely low distortion and low $\mathrm{d} v / \mathrm{dt}$ of the output voltage; (2) low distortion input current draw with structure-type filters (such as LCL filters) simplified to L filters; (3) low switching frequencies that would significantly reduce switching loss; (4) smaller common-mode $(\mathrm{CM})$ voltage to reduce the stress in motor bearings. In addition, the CM voltage could be eliminated by using proper methods [14].

A great deal of work related to the multi-level converter topology, control schemes, and their applications has been done in the last ten years [15-17]. Mondal et al. [18] extended the space voltage pulse width modulation (SVPWM) of the three-level inverter into the over-modulation region. Busquets-Monge et al. [19] presented a new modulation approach for the complete control of the neutral-point voltage in a three-level three-phase NPC voltage source inverter. The modulation approach 
was based on the virtual space vector concept, which guarantees the balancing of the neutral-point voltages for any load (whether linear or nonlinear) over the full range of converter output voltage and for all load power factors, with the only requirement being that the sum of the three-phase output currents is zero. Implementing the modulation was simple based on the phase duty-ratio expressions. A hybrid PWM modulation scheme [20] that uses both SVPWM and virtual SVPWM (VSVPWM) was presented, and allowed for complete control of the neutral point voltage in NPC three-level inverters, the performance of which was verified through simulation and experiment. In addition to the advanced modulation scheme, Verveckken et al. [21] developed a direct power control (DPC) method based on instantaneous power theory to apply the full potential of a power converter to a grid-connected system. Another typical application of multi-level converters is in AC motor driving systems where direct torque control (DTC) of induction motors using NPC three-level converters was described in [22-24].

The aim of this paper is to further extend sliding mode control to ERLPBTS using a three-level NPC converter. This is based on the work done in $[25,26]$, but differs from previous research in that, for the first time, the inner current decoupling control method combined with sliding mode control is illustrated, along with an optimal switching table for the convergence of an equivalent input voltage for an NPC-based voltage source converter. The surface derivation and the principle of decoupling between phases are presented. Specifically, comparisons between the proposed scheme (sliding mode control) and the conventional proportional integral (PI) control scheme in the discharging current test of the PBPTS are presented. Another contribution of this paper is the elimination of the need for an isolation transformer, which makes the system more efficient as well as being lighter and smaller in volume.

This paper is arranged as follows: in Section 2, we explain the configuration and operation principles of the ERLPBPTS when it works in discharging mode. In Section 3, the saturation-restrained inner sliding model controlled current decoupling control scheme which is combined with an optimal switching table, are designed to integrate the three-level inverter to an AC-grid. We also design a fast dynamic time response current controller for discharging tests with minimum overshoot by establishing the dynamic equation of the small signal average model. In Section 4, simulations are performed to demonstrate the feasibility and correctness of the recommended scheme. The hardware setup and experimental results to verify the proposed scheme are given in Section 5. Finally, conclusions and suggested future works are presented in Section 6.

\section{Configuration, Operation Principle, and Mathematical Model of NPC-Based Transformerless Three-Level ERPBPTS}

\subsection{Composite Power Circuit Description}

The diagram of the improved ERLPABTS is shown in Figure 1. It is used for the two-channel ERPBPTS. Compared with conventional two-level ERLPABTS system in [11], it is easily seen that there is no isolation transformer in the power circuit. The three-phase AC-DC rectifier/inverter and the DC-DC buck-boost chopper are composed of a three-level diode-clamped NPC-VSC converter. Hence, the configuration of the whole system contains the following parts:

(a) A three-phase breaker on grid-side for short circuit protection;

(b) Three $L$-type filters for higher-order current harmonic elimination; 
(c) A three-phase, three-line, three-level NPC-VSC inverter/rectifier on the inverter side;

(d) A dual-channel DC-DC buck-boost chopper for charging and discharging control of the power accumulator battery pack;

(e) Two large value DC current filter inductors in channels A and B are used to minimize the current ripple while performing current test experiments;

(f) The DC-DC buck and boost chopper shares the same dc-link voltage. Large value and volume DC-bus capacitors are needed to keep the dc-link voltage constant;

(g) Dual channel power battery packs for load testing, which can be a lead-acid battery, lithium-ion battery, or super-capacity battery.

Figure 1. Block diagram of the ERLPABTS using an improved NPC-VSC converter.

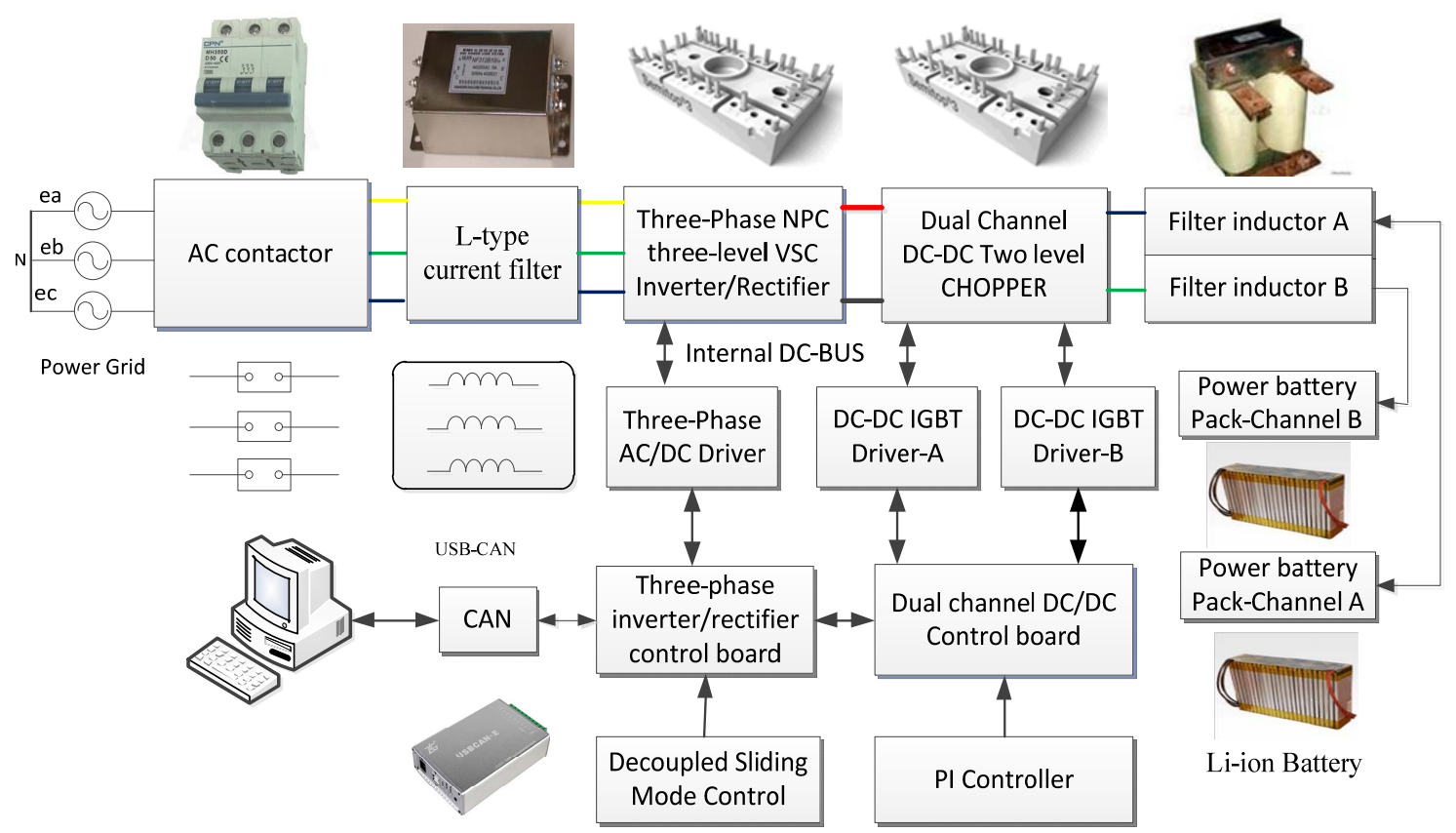

The detailed parameters of the above components for the simulation and experiments are provided in Tables A1 and A2. In our previous work [11], a fundamental frequency transformer has to be used to match the voltage between the grid-side and the converter side. In order to reduce the total output current harmonic, an LCL type filter is usually used to reduce the current harmonic distortion, but, this creates the problems because of the complicated control algorithm and the resonance, which is usually addressed through active damping control [27]. However, the present system does not have these drawbacks since the output voltage of the NPC-VSC converter is closer to sinusoidal. Furthermore, an $L$ filter might be used for a simplified implementation of a three-level converter.

Besides the current filter, in the proposed scheme, two digital signal processing (DSP) control boards are needed to control the AC-DC converter and the DC-DC converter, respectively. The controller for the AC-DC converter is responsible for the unity power factor grid-connected control, while, in Figure 2, the DC-DC converter utilizes T5 in the buck chopper for charging control and T6 in the boost chopper for discharging control. 
Figure 2. Power circuit topology of the ERLPABTS using the NPC-VSC converter.

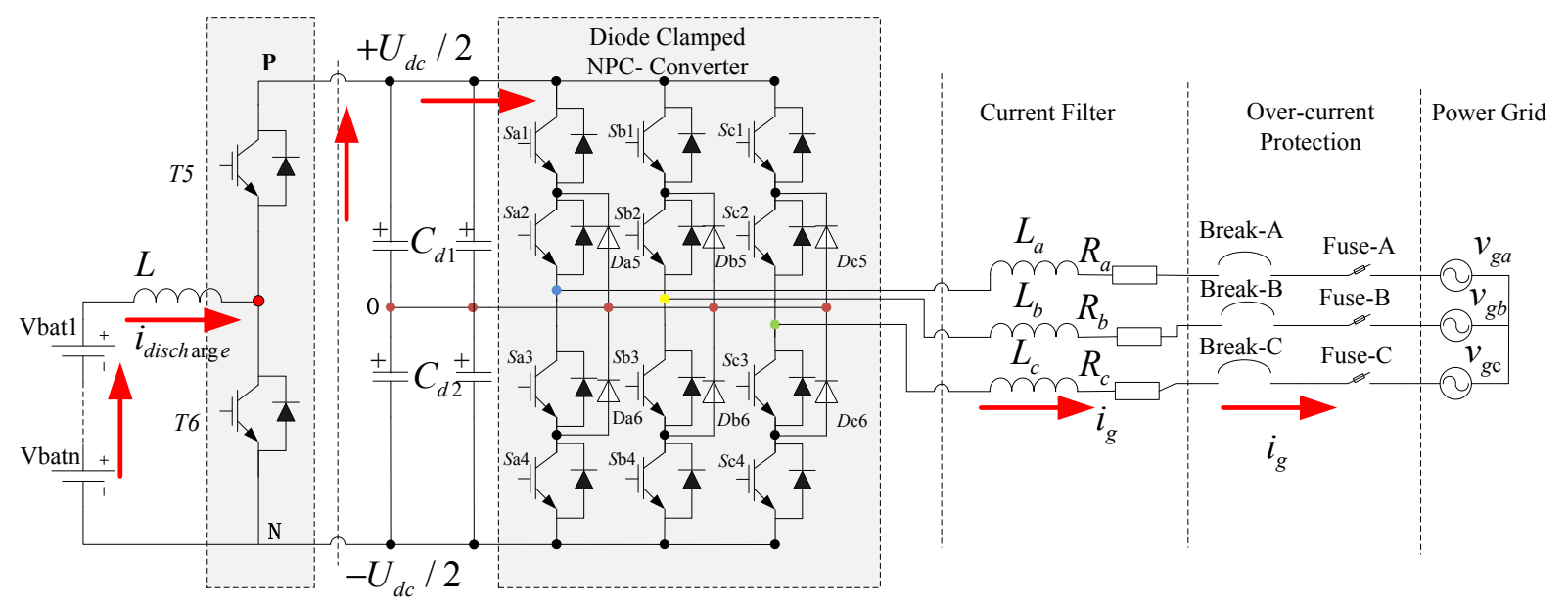

In summary, the key advantages of the proposed three-level converter in ERLPABTS are: it can handle higher and multi-level voltages with low total harmonic distortion (THD), it has a, low power transistor voltage rating requirement, and it eliminates the need for complicated filters or bulky and low efficiency isolation transformers. All of these features make the improved power circuit topology superior to that of the conventional system.

\subsection{Operation Principle}

The detailed schematic power circuit topology of the improved NPC-based three-level grid-connected system for ERPBPTS is shown in Figure 2, It is different from the conventional two-level converter in [11], because there are a total of twelve additional power transistors, and six additional voltage clamped power diodes. The ERLPABTS, therefore, has three output voltage levels: $+U_{\mathrm{DC}} / 2,0$, and $-U_{\mathrm{DC}} / 2$. Due to the merits of a three-level converter, a simplified $\mathrm{L}$ type interface filter might be adopted for current filtering. A bi-directional buck and boost chopper is used for the charging and discharging current control of the power battery pack.

The operating principle of the proposed power circuit is described as follows: when the discharging current test experiment is performed, the DC-DC converter functions as a boost chopper and $T 6$ is switched ON and OFF with the PWM. A constant charging current is obtained via the bypass diode of T5, which causes an increase in the DC-link voltage. The power transistor would be damaged through the high-voltage break down if it were not properly controlled. This energy is released to the power grid through a three-level NPC converter system. An energy balanced control strategy between the DC-DC converter and the DC-AC converter would be the most important consideration. In this way, the discharging energy could be recovered effectively, which could realize a high resolution discharging current test at the same time. A current filter, over-current protection devices, and fast-acting fuses are also used for protection. In summary, the control part of the system includes two branches: the first is the controller design for the non-isolating DC-DC boost chopper, and the second is the controller design for the energy recovery control of the ERLPABTS.

Considering the time response requirement of ERLPABTS, the instantaneous charging and discharging current control capability of the power battery pack must be evaluated. The traditional 
proportional and integral (PI) controller in PABPTS cannot satisfy the dynamic parameter requirements of the battery testing system. Sliding mode control (SMC) has the advantages due to its insensitivity to modeling error, variation on the parameters, and external disturbance. Moreover, sliding mode control can provide much faster dynamic response, especially in the unfixed structure and time-variant of a grid connected inverter. Therefore sliding mode control could obtain better performance than a conventional PI controller in this application.

\section{Sliding Mode Controller Design for ERLPABTS under Discharge Mode}

\subsection{Decoupled Sliding Mode Controller Design for the NPC VSI Based Grid-Connected System}

Since the mathematical mode of the three-phase NPC VSI converter for ERPABPTS has already been elaborated in our aforementioned word in [25,26], the decoupled sliding mode controller for the system would be discussed in detail in this paper. Sliding mode control is a variable structure control that selects the suitable switching configuration of the converter to drive the trajectory toward a predefined switching surface. When a system governed by sliding mode control reaches the control surface, it is forced to constrain its dynamic evolution on this surface for all subsequent time. The system dynamics restricted to this surface represent the controlled system behavior. The previous step for the controller design consists of choosing a suitable sliding surface. The controller will be designed in order to force the output function to track a reference signal. Assuming that the error between reference active and reactive current $\left(i_{\mathrm{d}}{ }^{*}, i_{\mathrm{q}}{ }^{*}\right)$ and feedback current $\left(i_{\mathrm{d}}, i_{\mathrm{q}}\right)$ could be expressed as: $s_{\mathrm{d}}=i_{\mathrm{d}}{ }^{*}-i_{\mathrm{d}}, s_{\mathrm{q}}=i_{\mathrm{q}}{ }^{*}-i_{\mathrm{q}}$. The sliding mode controller for the active and reactive current component could be represented as $G_{\mathrm{d}}\left(s_{\mathrm{d}}, \mathrm{d} s_{\mathrm{d}} / \mathrm{d} t\right)$ and $G_{\mathrm{d}}\left(s_{\mathrm{q}}, \mathrm{d} s_{\mathrm{q}} / \mathrm{d} t\right)$, respectively, and the duty cycle $\left(D_{\mathrm{d}}, D_{\mathrm{q}}\right)$ under synchronous rotating reference frame can be revised as:

$$
\left\{\begin{array}{l}
D_{d}=2 \cdot\left(G_{d}\left(s_{d}, \dot{s}_{d}\right) \cdot\left(s_{d}+\frac{\mathrm{ds}_{d}}{d t}\right)-\omega L \cdot i_{q}+e_{d}\right) / v_{d c} \\
D_{q}=2 \cdot\left(G_{q}\left(s_{q}, \dot{s}_{q}\right) \cdot\left(s_{q}+\frac{\mathrm{d} s_{q}}{d t}\right)+\omega L \cdot i_{d}+e_{q}\right) / v_{d c}
\end{array}\right.
$$

According to the requirement of the sliding mode control method, the selection of the control input components $u_{\text {eqd }}$ and $u_{\text {eqq }}$ must satisfy the arriving condition which means:

$$
s_{d} \cdot \dot{s}_{d}<0 \quad s_{q} \cdot \dot{s}_{q}<0
$$

When $s_{\mathrm{d}}=s_{\mathrm{q}}=0$, the equivalent control input voltage components $u_{\text {eqd }}$ and $u_{\text {eqq }}$ can be shown as:

$$
\left\{\begin{array}{l}
\frac{d i_{d}^{*}}{d t}=\frac{d i_{d}}{d t}=-\frac{R}{L} \cdot i_{d}+\omega \cdot i_{q}+\frac{1}{L} \cdot v_{e q d}-\frac{1}{L} \cdot e_{d} \\
\frac{d i_{q}^{*}}{d t}=\frac{d i_{q}}{d t}=-\omega \cdot i_{d}-\frac{R}{L} \cdot i_{q}+\frac{1}{L} \cdot v_{e q q}-\frac{1}{L} \cdot e_{q}
\end{array}\right.
$$

In Equation (3), $v_{\text {eqd }}$ and $v_{\text {eqq }}$ represent the input equivalent voltage components. Combining Equation (3) with Equation (2), we can derive the differential equations of the components $s_{\mathrm{d}}$ and $s_{\mathrm{q}}$ as: 


$$
\left\{\begin{array}{l}
\frac{d i_{d}}{d t}-\frac{d i_{d}^{*}}{d t}=\frac{v_{d c}}{L}\left(v_{d}-v_{e q d}\right)=\frac{d s_{d}}{d t} \\
\frac{d i_{q}}{d t}-\frac{d i_{q}^{*}}{d t}=\frac{v_{d c}}{L}\left(v_{q}-v_{e q q}\right)=\frac{d s_{q}}{d t}
\end{array}\right.
$$

Considering Equations (2) and (4) with respect to the arriving condition, then

$$
\left\{\begin{array}{l}
s_{d} \cdot\left(v_{d}-v_{e q d}\right)<0 \\
s_{q} \cdot\left(v_{q}-v_{e q q}\right)<0
\end{array}\right.
$$

Therefore, the equivalent control input must satisfy the following condition (6) to force the movement trajectory to be convergent to pre-defined sliding mode plane:

$$
\left\{\begin{array}{l}
\operatorname{sgn}\left(v_{d}-v_{\text {eqd }}\right)=\operatorname{sgn}\left(s_{d}\right) \\
\operatorname{sgn}\left(v_{q}-v_{\text {eqq }}\right)=\operatorname{sgn}\left(s_{q}\right)
\end{array}\right.
$$

The sliding mode current controller must be designed to satisfy Equation (6), where $v_{\mathrm{d}}$ and $v_{\mathrm{q}}$ are the voltage components needed to be composited. Space vector pulse width modulation could be used the composite the needed voltage, this has been illustrated in reference [16,28,29]. Yet, this need complicated mathematic computation for Clark and Park transformations, due to this, faster and higher micro-controller is needed. In this paper, to simply the control algorithm, an optimized switching table is put forward and used. It is shown in Table 1, the optimized switching table can avoid duplicate cross zone power transistor switching. From Equation (6), we may conclude that the error signal between input voltage $v_{\mathrm{d}}$ and equivalent input voltage $v_{\text {eqd }}$ for active power component decides the output signal of switch $S_{\mathrm{p}}$, and the error between input voltage $v_{\mathrm{q}}$ and equivalent input voltage $v_{\text {eqq }}$ for reactive power control decides the output signal of switch $S_{\mathrm{q}}$. In order to acquire the current location of which the grid voltage vector, the angle information of grid-connected voltage $\theta$ can be calculated by $e_{\alpha}$ and $e_{\beta}$ which is shown as: $\theta=e_{\beta} / e_{\alpha}$, twelve sectors are divided in one cycle, $\theta$ is the current location of grid-side voltage vector and it can be calculated as:

$$
(n-2) \cdot \frac{\pi}{6} \leq \theta_{n} \leq(n-1) \cdot \frac{\pi}{6}
$$

\begin{tabular}{|c|c|c|c|c|c|c|c|c|c|c|c|c|c|}
\hline$S_{\mathrm{p}}$ & $S_{\mathrm{q}}$ & $\theta_{1}$ & $\theta_{2}$ & $\boldsymbol{\theta}_{\mathbf{3}}$ & $\theta_{4}$ & $\theta_{5}$ & $\theta_{6}$ & $\boldsymbol{\theta}_{7}$ & $\theta_{8}$ & $\theta_{9}$ & $\theta_{10}$ & $\theta_{11}$ & $\theta_{12}$ \\
\hline \multirow{2}{*}{1} & 0 & 101 & 111 & 100 & 000 & 110 & 111 & 010 & 000 & 011 & 111 & 001 & 000 \\
\hline & 1 & 111 & 111 & 000 & 000 & 111 & 111 & 000 & 000 & 111 & 111 & 000 & 000 \\
\hline \multirow{2}{*}{0} & 0 & 101 & 100 & 100 & 110 & 110 & 010 & 010 & 011 & 011 & 001 & 001 & 101 \\
\hline & 1 & 100 & 110 & 110 & 010 & 010 & 011 & 011 & 001 & 001 & 101 & 101 & 100 \\
\hline
\end{tabular}

In Equation (7), the section number $n=(1,2, \ldots, 12)$.

Table 1. Optimized switching table for the proposed scheme. 


\subsection{Active and Reactive Current Component Generation}

It should be noted that unlike conventional VSI converters, there is no constant power source voltage in the DC-bus. The voltage is decided by the discharging current and the battery pack's terminal voltage on the boost converter side, which charges the electrolytic capacitors on the DC-bus and results in fast dc-link voltage climbing rates. Thus, a reference current for integrating the grid is used to maintain a constant DC-link voltage, and a switch is needed to control whether it is integrated to the power grid. As the discharging energy is temporarily stored in the dc-bus capacitors, the active power component that needs to be recovered could be determined by multiplying the DC-link voltage $\left(v_{\mathrm{DC}}\right)$ and the DC-link current $\left(i_{\mathrm{DC}}\right)$ as:

$$
p_{\text {ref }}=v_{\mathrm{dc}} \cdot i_{\mathrm{dc}}
$$

Based on the active and reactive current component references by [11], we may conclude that the active and reactive current component reference $\left(i_{\mathrm{d}}{ }^{*}, i_{\mathrm{q}}{ }^{*}\right)$ can be represented as:

$$
\left\{\begin{array}{l}
i_{d}^{*}=\frac{2}{3} \cdot \frac{\left(v_{\mathrm{dc}} \cdot i_{\mathrm{dc}} \cdot v_{d}+q_{r e f} \cdot v_{q}\right)}{v_{d}^{2}+v_{q}^{2}} \\
i_{q}^{*}=\frac{2}{3} \cdot \frac{\left(v_{\mathrm{dc}} \cdot i_{\mathrm{dc}} \cdot v_{q}-q_{r e f} \cdot v_{d}\right)}{v_{d}^{2}+v_{q}^{2}}
\end{array}\right.
$$

When under a synchronous rotating frame and assuming that the reference reactive power component and voltage component are $q_{\mathrm{ref}}=0$ and $v_{\mathrm{d}}=0$, respectively, Equation (9) can be rewritten as:

$$
i_{d}^{*}=0 \quad i_{q}^{*}=\frac{2}{3} \cdot \frac{v_{\mathrm{dc}} \cdot i_{\mathrm{dc}}}{v_{q}}
$$

Considering the decoupled control scheme proposed in [11] and the optimal switching table for output voltage vector, the control diagram of the whole system would be illustrated in Figure 3 as:

Figure 3. Control block diagram of the composite power converter system for ERLPABTS.

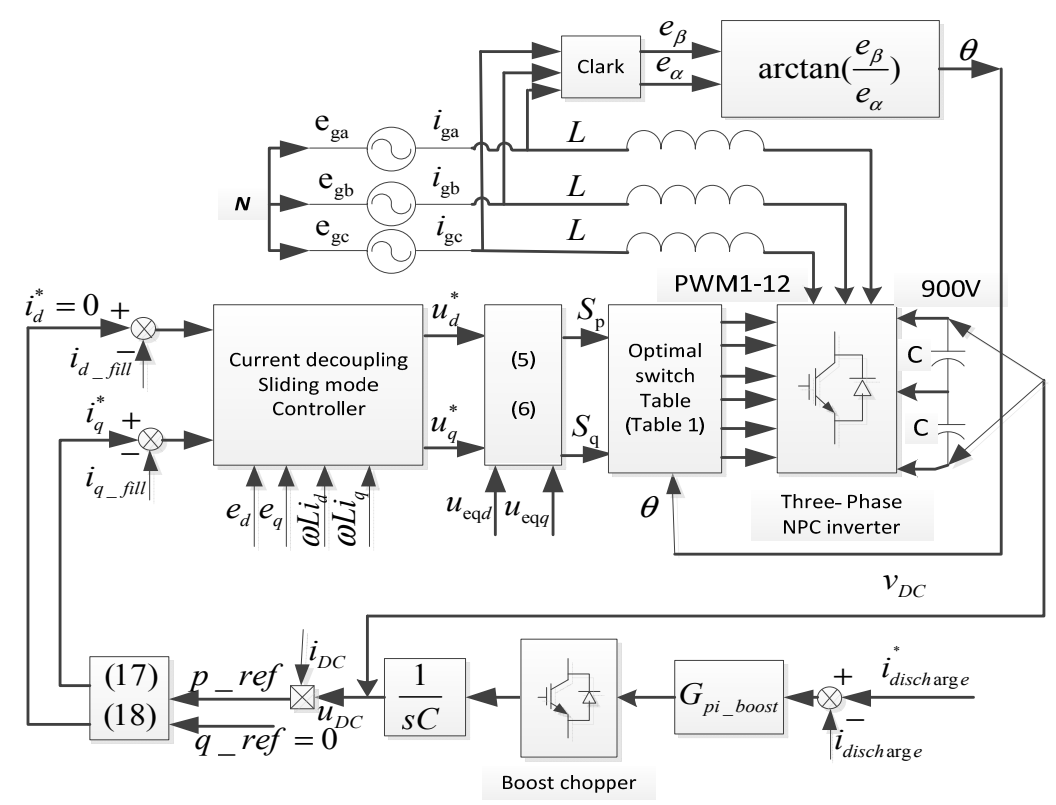




\subsection{Dynamic Model of the DC-DC Boost Chopper for Discharging Current Control of ERPBTS}

The boosting chopper is used for a constant current discharging test experiment of a power accumulator battery pack testing system. The reason that a switching mode DC-DC power converter is used instead of a linear mode controlled power transistor which works in a linear area is that it has the ability to process a large discharging testing current with much a higher DC-bus voltage and minimum switching loss. However, the switching mode DC-DC converter has a shortcoming because of the current ripple on each switching point and thus a large amount of electronic noise might occur in this case. A mathematical model and its related non-linear control of the boost chopper were given in [11], while an optimal minimum time response current control scheme under the maximum and minimum voltages and the current limitation for ERPBTS was previously proposed in [25]. Therefore this paper focuses on the combination of two power circuits, which include a DC-DC buck and boost chopper and an NPC three-level converter, the latter of which is used for integration into a power grid with high voltage and low total harmonic distortion.

\section{Simulation Results and Discussion}

Simulations for integrating the three-phase NPC inverter with the distribution grid using an $L$ filter interface in a Powersim 9.0 environment are carried out in order to describe and validate the capability of the proposed control scheme. The improved composite power circuit for ERPBTSs is verified through these simulations. The model is co-simulated using Matlab/Simulink and PSIM9.0 via a simcoupler block. The power circuit is established in Psim 9.0 environment and the control algorithm is realized in Simulink. The configuration and control block diagram of the system are shown in Figure 3, and the electrical parameters used for the simulation can be found in Tables A1 and A2 in the Appendix. The simulation study is performed with three main objectives in mind:

(1) To demonstrate the feasibility of the proposed control scheme for the composite power circuit.

(2) To verify the merits of reduced total harmonic distortion of a grid-connected current by using the proposed scheme and an optimized switching table in a three-level VSC converter.

(3) To realize the performance of the current decoupling scheme and the proposed sliding mode controller provided in Equation (6).

Figure 4 shows a PI control diagram of the composite power circuit for ERPBTS. The gain $(k)$ and time constant ( $T$ in seconds) of the PI controller in a discharging control test are set to $\left(k_{\mathrm{p}}=0.04\right.$, $T=0.012$ ). The transfer function of the PI controller used for $i_{\mathrm{d}}$ and $i_{\mathrm{q}}$ control is shown in Equation (11). The PWM duty cycle is calculated using Equation (9). Two signal generators are needed to obtain the positive and negative output sinusoidal waveform. The space vector voltage to be synthesized is realized by selecting a particular voltage vector depending on the composite voltage vector's present location:

$$
G_{p i}=0.04 \cdot \frac{(1+0.012 \cdot s)}{0.012 \cdot s}
$$

In this section, in order to verify the performance of a different controller, we will show the simulation results for the improved composite power circuit for ERLPABTS using sliding mode control and the PI controller method, respectively. 
Figure 4. Inner active and reactive current component control using PI method.

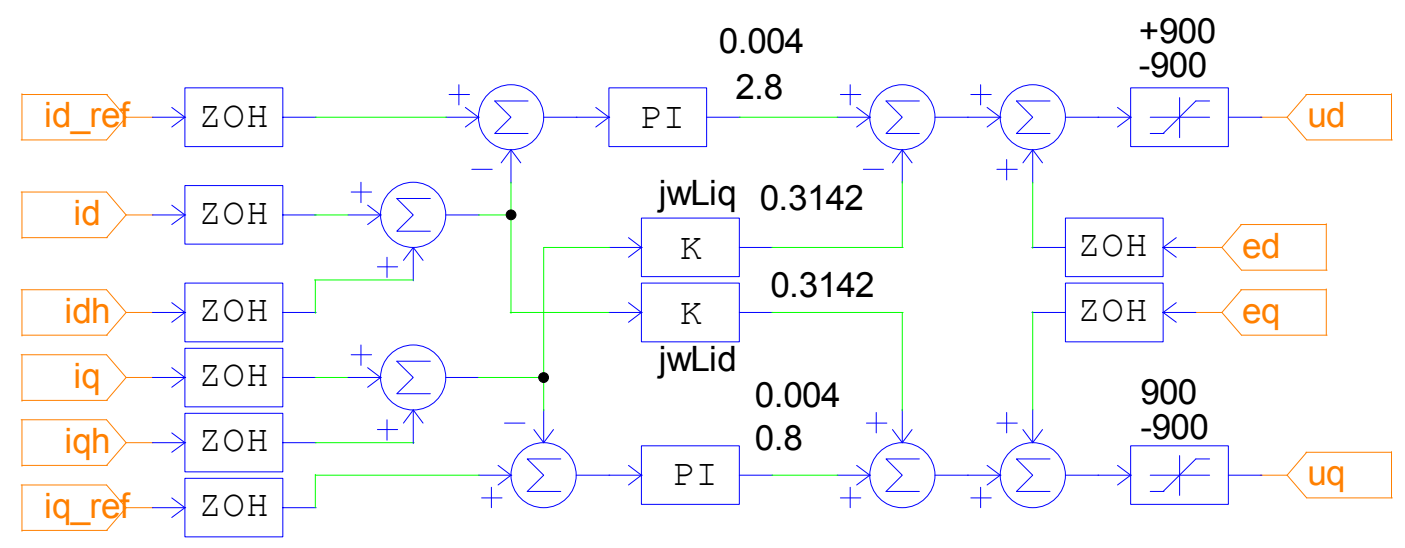

Figure 5a shows the waveform of the reference discharging current and feedback current. A step-forward reference current of $400 \mathrm{~A}$ is given at $0.03 \mathrm{~s}$ and the feedback current keeps track of its reference current with a peak value of 10 A overshot $20 \mathrm{~ms}$ later. This demonstrates the feasibility of the proposed scheme.

Figure $5 \mathrm{~b}$ gives the waveform of a dc-link voltage $v_{\mathrm{dc}}$ that is set to $900 \mathrm{~V}$ using a switch that enables and disables PWM modulation to keep the dc-link voltage constant. The initial dc-link capacitor voltage is pre-charged to $800 \mathrm{~V}$ to prevent an instantaneous charging current when powered on. It can be clearly seen that the dc-link voltage remains steady and stable.

Figure 5c shows the waveform of the active and reactive powers ( $P_{-}$ref, $Q_{-}$ref) reference where the active power (P_ref) is given by Equation (8) and the reference reactive power ( $\mathrm{Q}$ ref) is set to 0 to realize unity power factor control.

It can be seen that there is a time difference between the reference active power and the feedback active power which is due to the dc-link voltage. The simulation test showed that the grid-connected NPC-inverter starts to work only when the voltage reaches $900 \mathrm{~V}$, and it takes $10 \mathrm{~ms}$ to charge from $800 \mathrm{~V}$ to $900 \mathrm{~V}$. The reference active power is $96 \mathrm{~kW}$, and the feedback active power can effectively keep track of its reference value.

Figure $5 \mathrm{~d}$ provides the time response of the grid-connected phase current $\left(i_{\mathrm{ga}}\right)$ and the grid voltage $\left(v_{\text {ga }}\right)$. It can be seen that the phase-current is almost in phase with the phase voltage, and that a unity power factor control is realized in the three-phase NPC inverter.

Figure $5 \mathrm{e}$ shows the time response of the active and reactive currents $\left(i_{\mathrm{d}}, i_{\mathrm{q}}\right)$ when using a sliding mode controller and PI controller (Figure 5f). The active and reactive current references are given by Equation (9) and it is found that the feedback current could track the reference current very well. However, there is steady state error $(\sim 5 \mathrm{~A})$ in this situation. The peak-to-peak active current value $\left(i_{\mathrm{p}-\mathrm{p}}\right)$ is about $50 \mathrm{~A}$. In order to compare the result when using different controllers, an extra inductor of $0.5 \mathrm{mH}$ is added to the system at $80 \mathrm{~ms}$, and is used to simulate the un-modeled parameter variations. It can be clearly seen that the active and reactive current components $\left(i_{\mathrm{d}}, i_{\mathrm{q}}\right)$ are influenced from 0 A to $50 \mathrm{~A}$. The active and reactive current components when using the sliding mode controller vary from $0 \mathrm{~A}$ to $-25 \mathrm{~A}$, which is half of the variation when using the PI controller. This demonstrates that the proposed controller is insensitive to parameter variations, and is superior to the conventional PI controller. 
Figure 5. Simulation results of the proposed scheme. (a) Time response of reference discharging current and feedback current; (b) Time response of dc-link voltage; (c) Time response of reference active and reactive power; (d) Time response of the grid-connected phase current $\left(i_{\mathrm{ga}}\right)$ and grid voltage $\left(v_{\mathrm{ga}}\right)$; (e) Time response of the active and reactive currents $\left(i_{\mathrm{d}}, i_{\mathrm{q}}\right)$ using a sliding mode controller; (f) Time response of the active and reactive currents $\left(i_{\mathrm{d}}, i_{\mathrm{q}}\right)$ using PI controller.

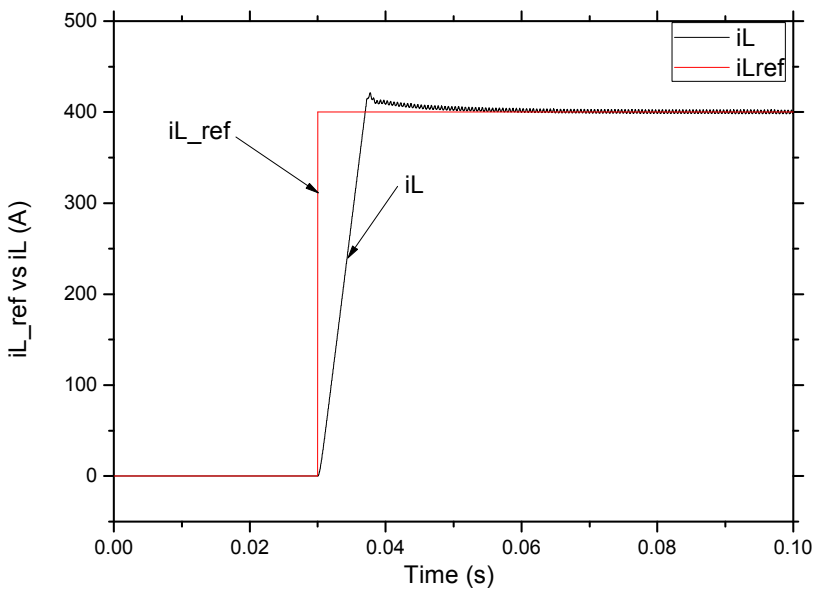

(a)

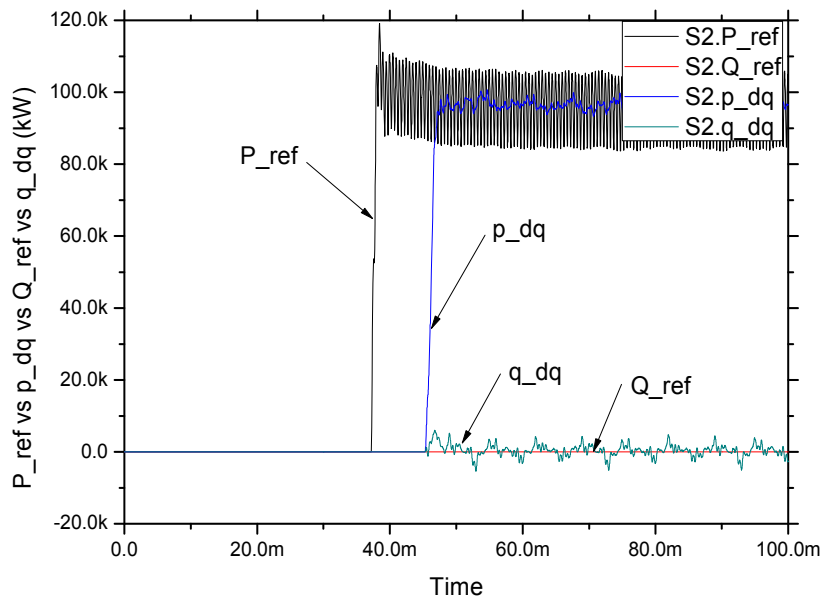

(c)

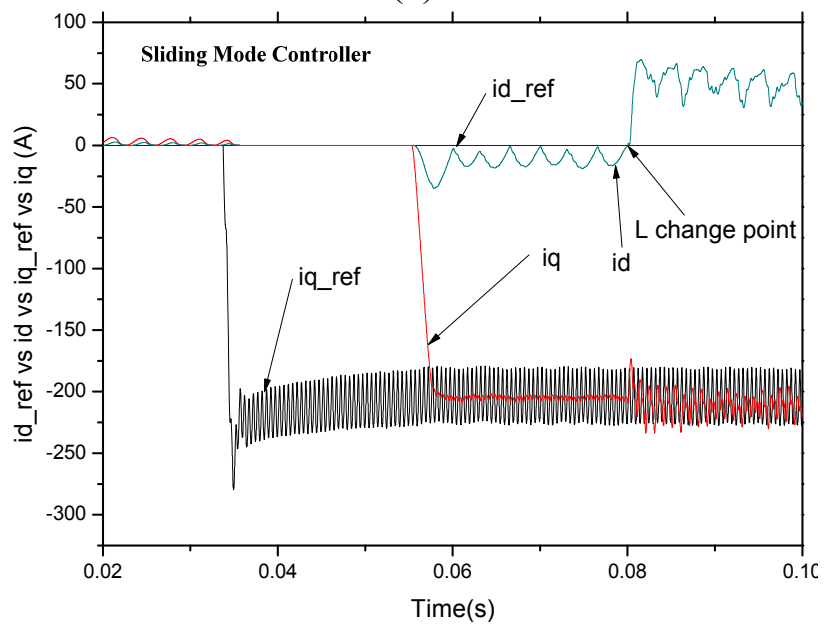

(e)

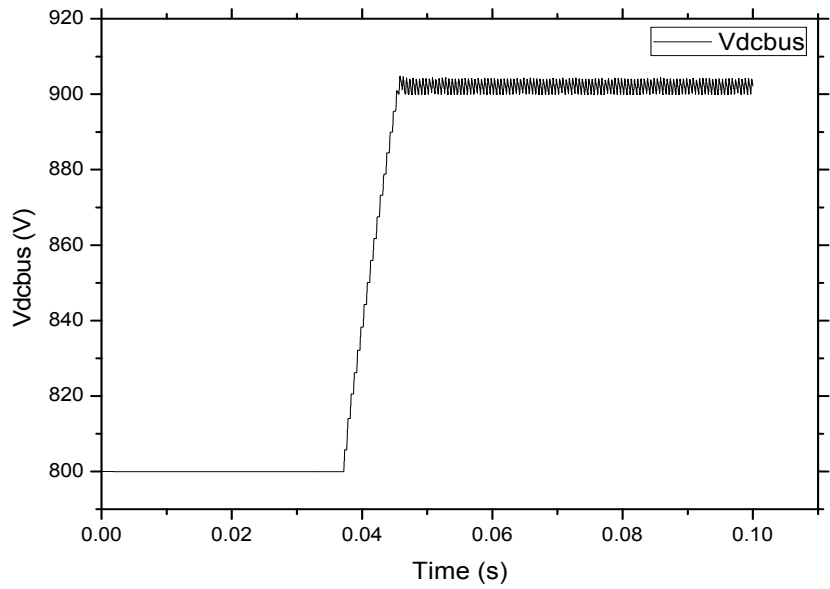

(b)

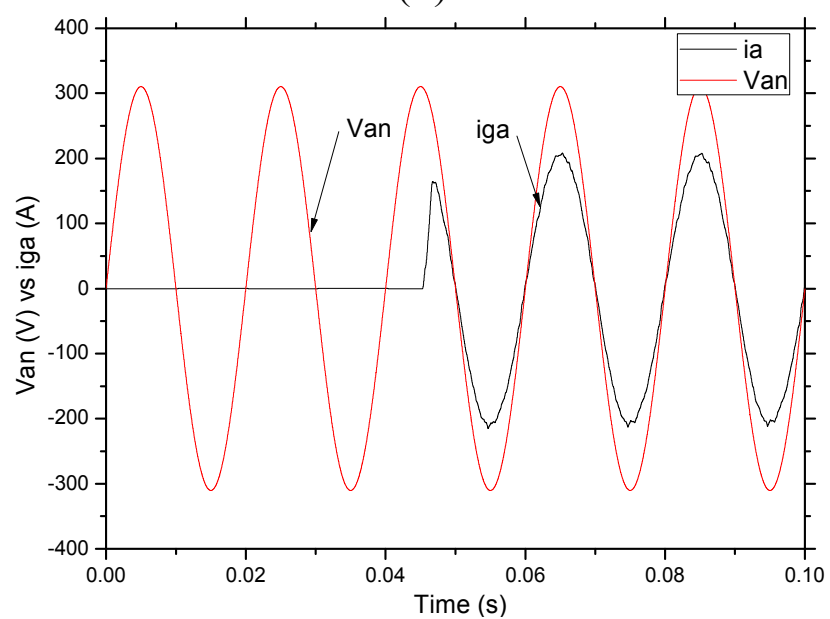

(d)

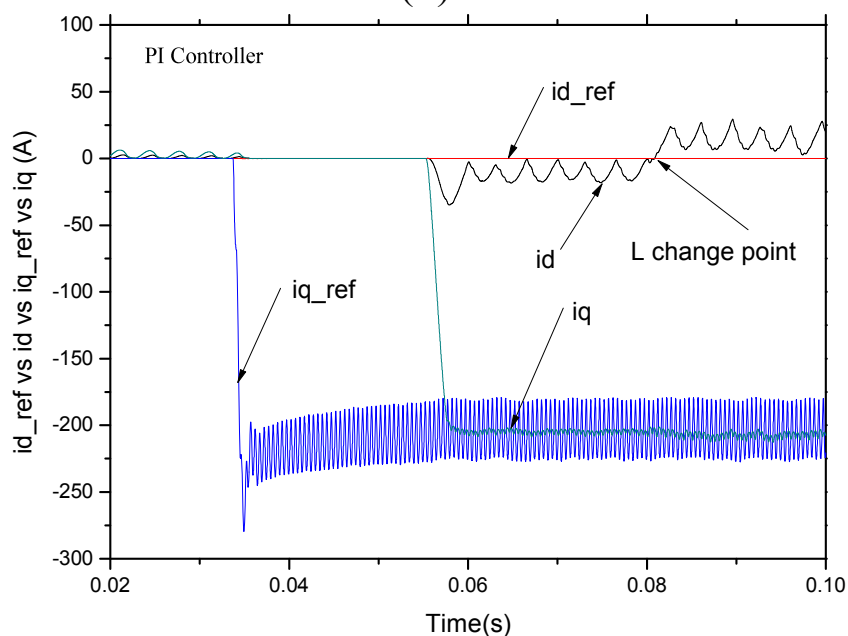

(f) 
Figure 6a shows the time response of the line-to-line voltage using a three-level converter without a transformer, while Figure $6 \mathrm{~b}$ gives the time response of the line-to-line voltage using a two-level converter. We can see that the voltage in Figure 6a is more sinusoidal due to its multiple output levels. Figure 7a illustrates the harmonic distribution of the phase current using a conventional two-level inverter, and Figure $7 \mathrm{~b}$ shows the NPC based three-level power converter. The conventional two-level converter has more harmonics since its total harmonic distortion is $16 \%$ while that of an NPC-based three-level VSC converter is only $2.11 \%$.

Figure 6. Line-to-line output voltage of the (a) three-level NPC-VSC converter and (b) two-level converter.

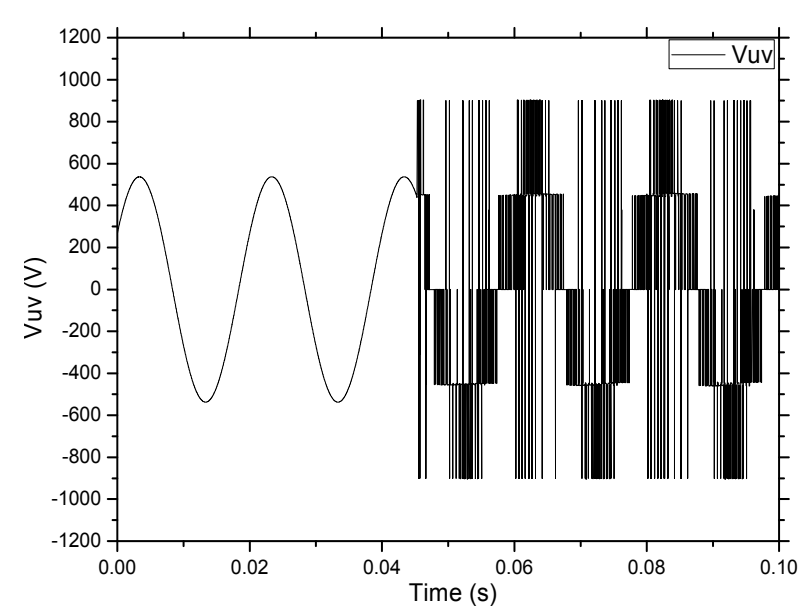

(a)

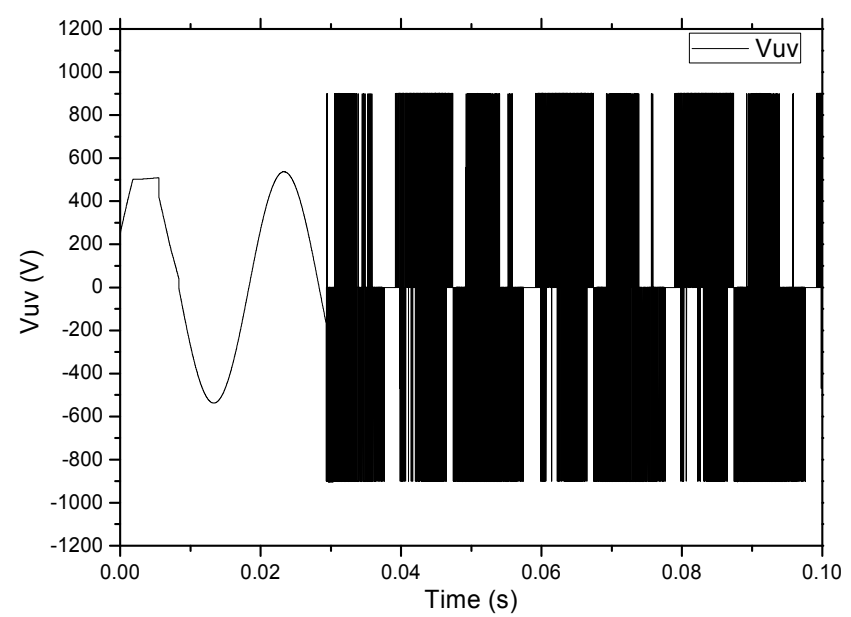

(b)

Figure 7. Harmonic distribution of the (a) three-level NPC-VSC converter and (b) two-level converter.

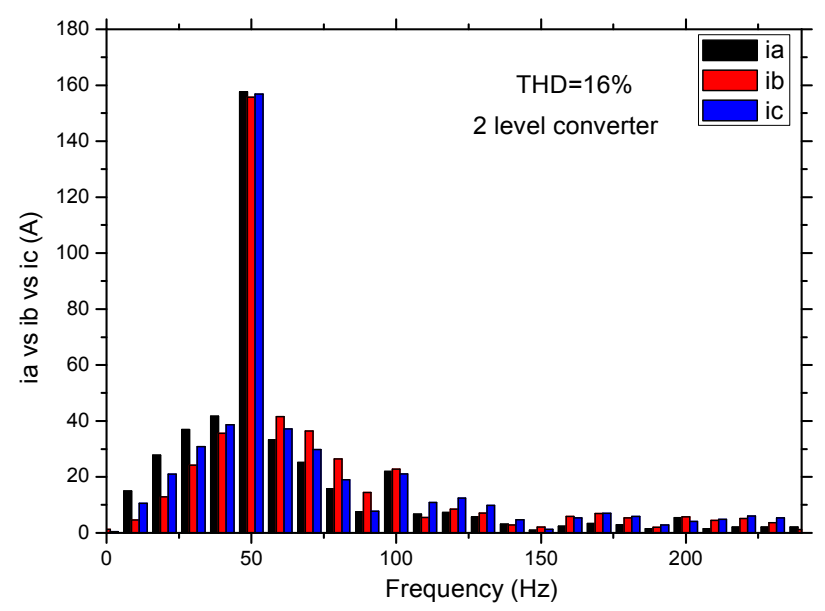

(a)

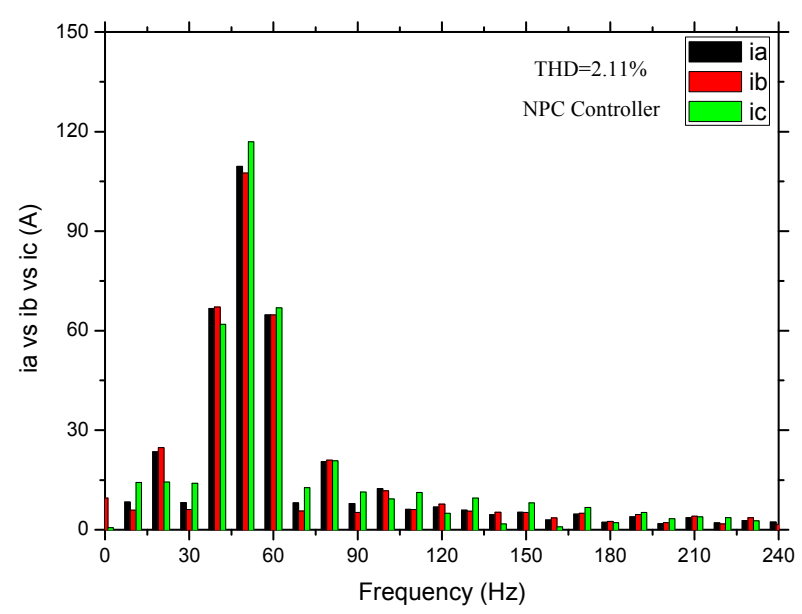

(b)

\section{Experimental Section}

A three-level NPC-VSC inverter, which is used for a grid-connected energy recovery Li-ion type power battery testing system experimental platform based on the DSP-TMS320LF2808, is setup to verify the proposed design. The hardware setup of the power circuit configuration of the system is shown in Figure 8a, while the IGBT driving, protection and core control board is shown in Figure 8b. 
The power input part of the two-channel ERLPABTS is presented in Figure 8c. The Li-ion battery used for experiment is presented in Figure 8d. System configuration of the experimental setup was illustrated in earlier sections via a block diagram, and the power transistor parameters are listed in Table A1 and Table A2 in the Appendix. The control scheme can be referenced in the simulation section.

Figure 8. The three-phase NPC inverter based ERLPABTS for the experiment. (a) Power circuit of the system; (b) IGBT driving, protection and core control board; (c) Power input of the two-channel ERLPABTS; (d) Li-ion battery used for experiment.

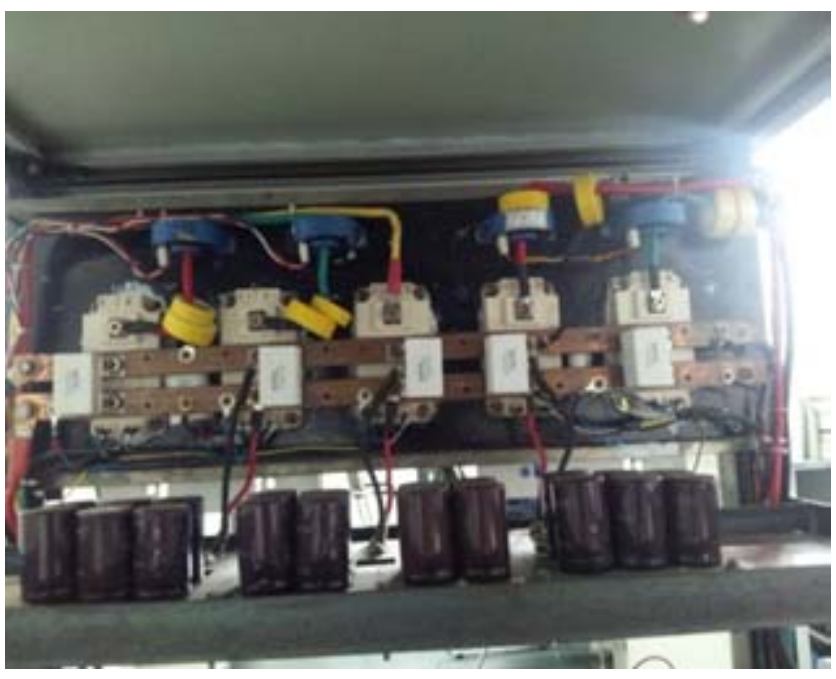

(a)

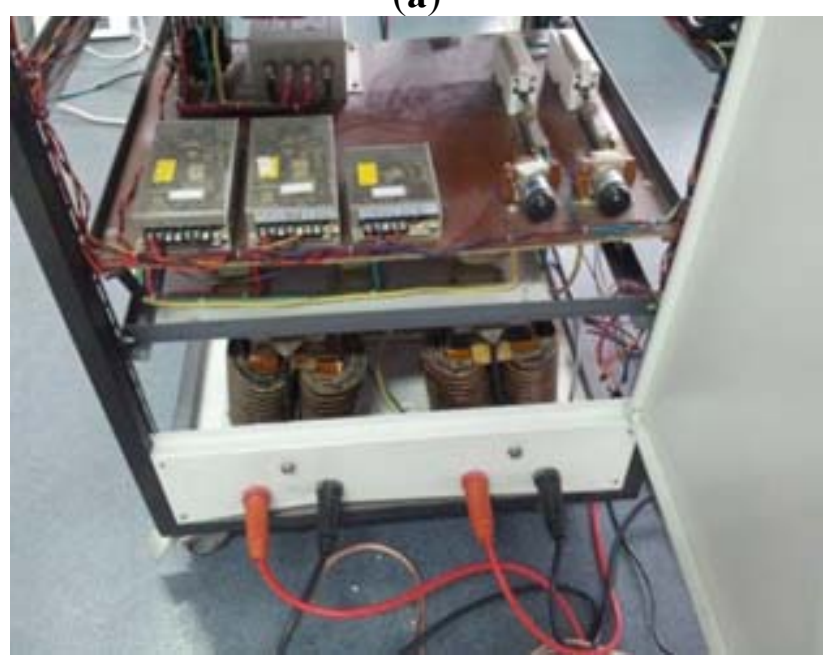

(c)

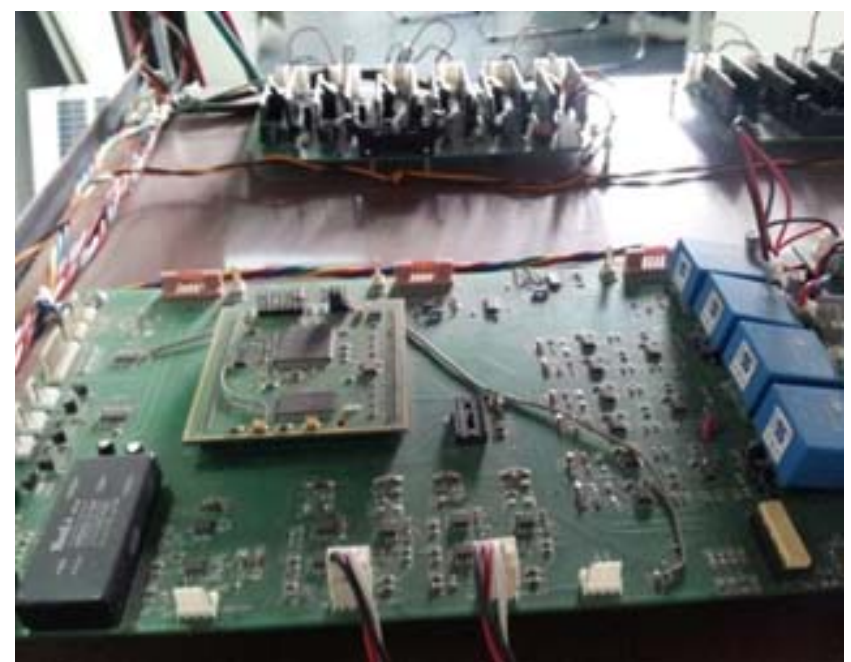

(b)

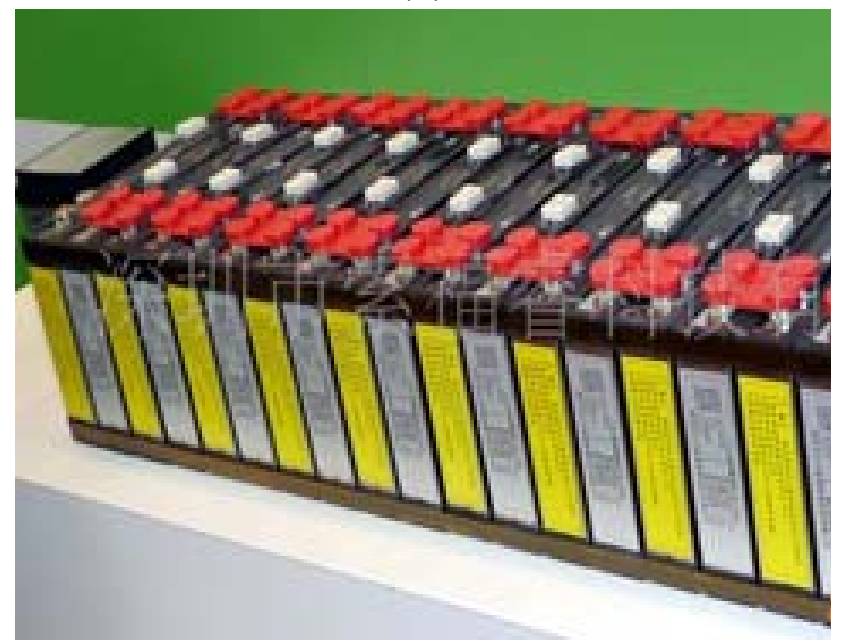

(d)

The power circuit of the PWM converter consists of six IGBT where each of the IGBT modules has two integrated IGBT blocks inside. This forms a three-phase NPC full-bridge inverter circuit and a half-bridge circuit, the electrical parameters of which are shown in Table 1 of the Appendix. Two Hall-effect LEM sensors (LT108-S7) and four isolation voltage sensors are used for the line currents and the DC-bus voltage detection. One high-resolution LEM sensor is employed to detect the charging and discharging currents in the DC-DC power circuit. A total of fourteen PWM output signals are required in the proposed scheme of which twelve are used for the three-phase NPC converter, while the others are used for the buck-boost chopping DC-DC converter. An optimized switch table for 
PWM generation is used for the attenuation of the active and reactive current components on the grid side, while the phase lock loop (PLL) control algorithm is used to obtain the precise angular information of the synthesized voltage vectors.

The experiments are implemented by changing the reference discharging current of the power battery pack. A step forward discharging current of $200 \mathrm{~A}$ is supplied at $20 \mathrm{~ms}$, which is then increased to $100 \mathrm{~A}$ at $60 \mathrm{~ms}$. The DC-bus voltage $\left(V_{\mathrm{dc}}\right)$ is set to $900 \mathrm{~V}$, and the DC-bus capacities are charged by the energy released from the boosting chopper control component which gives rise to its terminal voltage. The three-phase NPC converter stops working when the DC-link voltage falls below $900 \mathrm{~V}$ and it restarts when the DC-link voltage is higher than $900 \mathrm{~V}$. A small band could be used to keep the DC-bus voltage stable without using a high switching frequency. The reference of the active and reactive power varies according to the discharging current and the DC-bus voltage which keeps the energy balanced both in the boost chopper and inverter sides. The discharge energy of the battery power testing is therefore restored to the power grid with high efficiency.

The discharging current response of the power battery pack is shown in Figure 9a. The feedback current initially peaks at $225 \mathrm{~A}$ and then keeps track of the reference current after $10 \mathrm{~ms}$ when given a reference current of $200 \mathrm{~A}$ at $t=20 \mathrm{~ms}$. The feedback current initially drops to less than $100 \mathrm{~A}$ and then converges back to the command value $10 \mathrm{~ms}$ later when a step-down discharge current of $100 \mathrm{~A}$ is given at $t=60 \mathrm{~ms}$. An instantaneous inrush current is caused by the pure inductor load on the boost chopper side. A smaller filter inductance has drawbacks due to the large current ripples, but a large filter inductance results in a short time response and a large volume. An inductance of $4 \mathrm{mH}$ is adopted for this experiment.

The time response of the DC-bus voltage is shown in Figure 9b. The initial DC-bus voltage is set to $500 \mathrm{~V}$ which starts to increase at $t=20 \mathrm{~ms}$ and reaches $900 \mathrm{~V}$ about $2.5 \mathrm{~ms}$ later. The DC-bus voltage starts to increase again at $t=60 \mathrm{~ms}$ when a step-down current reference is given which is due to the reduced load on the DC-bus.

Figures $9 \mathrm{c}$ and $9 \mathrm{~d}$ illustrates the experimental results of the active and reactive current components $\left(i_{\mathrm{d}}\right.$ and $i_{\mathrm{q}}$ ) when the grid-connected interface inductor changes under the PI and SMC control methods, respectively. Compared with Figure 9c, the active and reactive current components in Figure 9d are influenced less by the grid-connected inductance variations ( $\pm 10 \mathrm{~A}$ in PI and $\pm 6 \mathrm{~A}$ ) when the inverter side inductor $\left(i_{\mathrm{g}}\right)$ changes from $1 \mathrm{mH}$ to $0.67 \mathrm{mH}$ at $120 \mathrm{~ms}$ and from $0.67 \mathrm{mH}$ to $1 \mathrm{mH}$ at $250 \mathrm{~ms}$, This demonstrates that by using the sliding mode controller, the system is insensitive to the parameter variations in the system. The improved control method could offer better robustness than the conventional method.

Figure $9 \mathrm{e}$ illustrates the time response of the active and reactive current components in the three-phase NPC converter. It shows that the reactive current component $\left(i_{\mathrm{d}}\right)$ converges to zero, and that the active current feedback $\left(i_{\mathrm{q}}\right)$ follows its reference component $\left(i_{\text {qref }}\right)$ very well when the DC-bus voltage increases to $900 \mathrm{~V}$.

To summarize, the experimental results confirm that the proposed scheme is not only feasible, but also valid and applicable. The proposed scheme could greatly improve conventional composite power circuits since the proposed novel system is more compatible, lighter, and less total grid current harmonic distortion. 
Figure 9. (a) Experimental results of time response vs. discharging current $\left(i_{\mathrm{L}}\right)$; (b) Experimental results of time response vs. dc-bus voltage $\left(V_{\text {dcbus }}\right)$; (c) Experimental results of active and reactive current components $\left(i_{\mathrm{d}}\right.$ and $\left.i_{\mathrm{q}}\right)$ when the grid connected interface inductor changes by using the PI method; (d) Experimental results of active and reactive current components $\left(i_{\mathrm{d}}\right.$ and $\left.i_{\mathrm{q}}\right)$ when the grid-connected interface inductor changes from $0.67 \mathrm{mH}$ to $1 \mathrm{mH}$ by using SMC method; (e) Experimental results for grid-connected current $\left(i_{\mathrm{a}}\right)$ and grid voltage of the system $\left(v_{\mathrm{an}}\right)$.

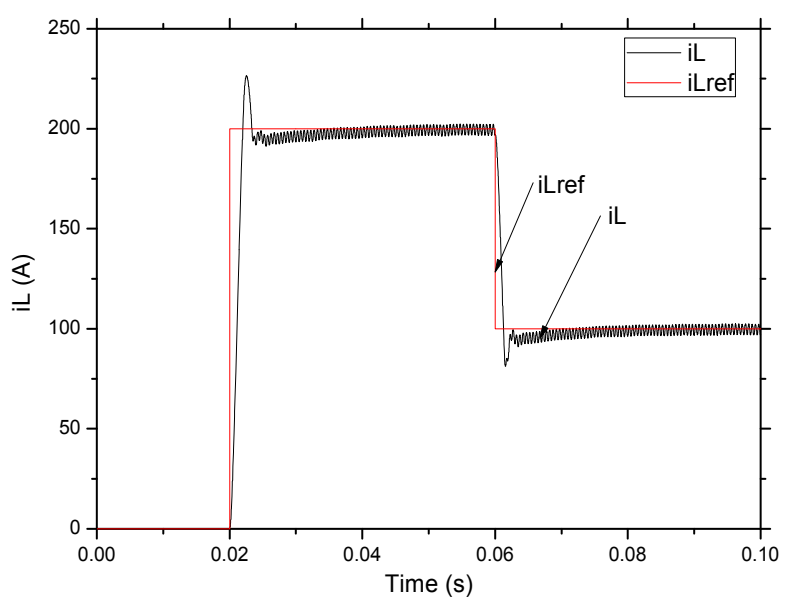

(a)

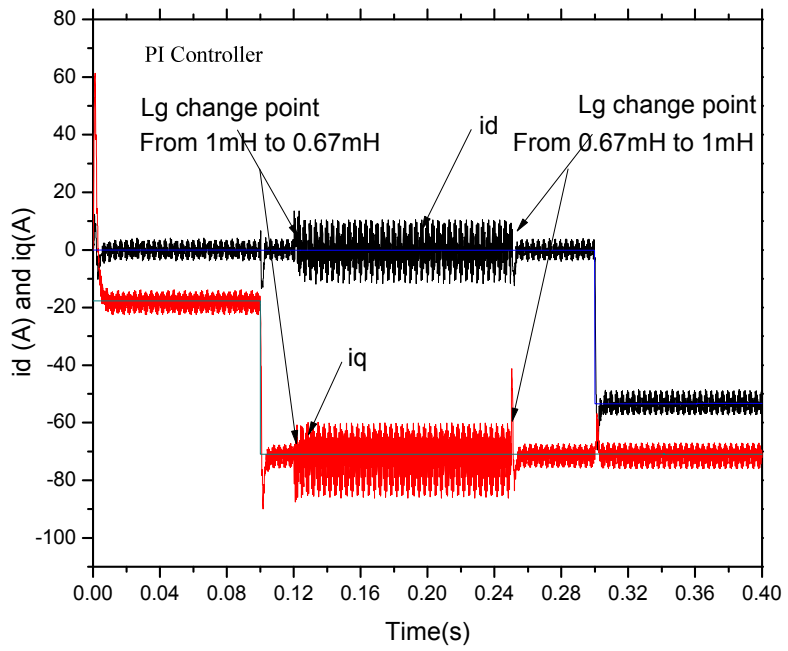

(c)

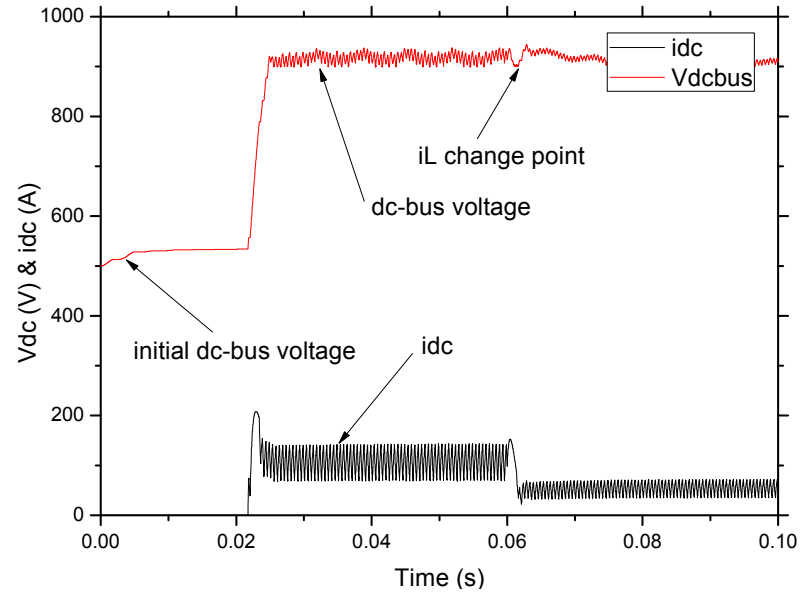

(b)

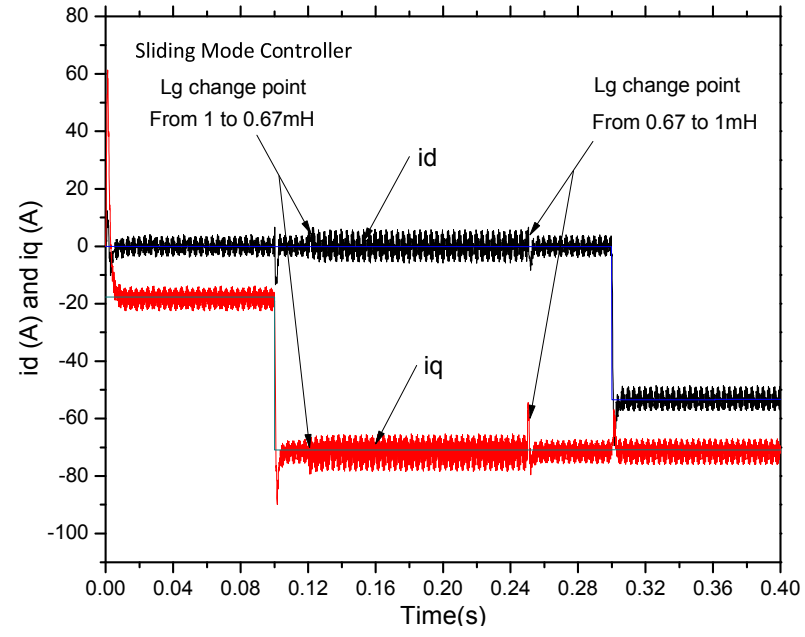

(d)

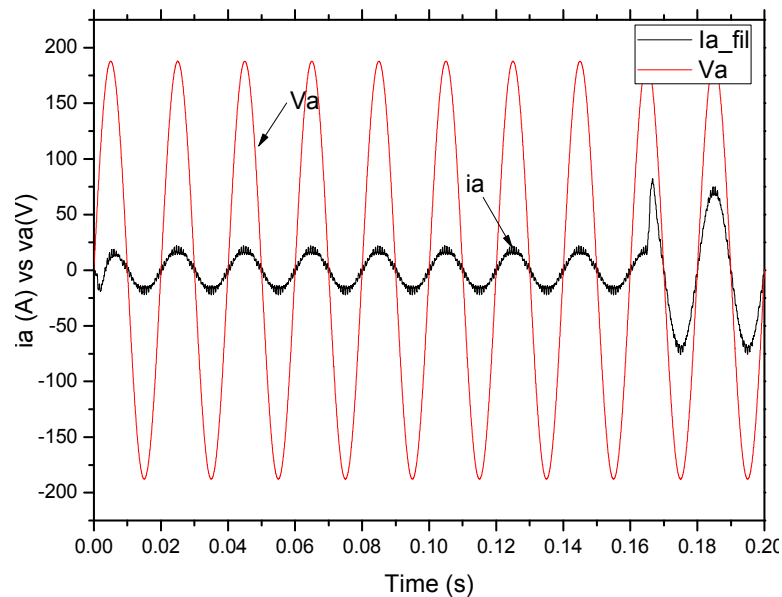

(e) 


\section{Conclusions}

This paper applies a three-level NPC-VSC power inverter to grid-connected ERLPABTSs. A sliding mode based current decoupling controller under a synchronous rotating reference frame is designed, and s-functions for the active current component $i_{\mathrm{d}}$ and the reactive current component $i_{\mathrm{q}}$ are proposed. Moreover, the performance of the proposed inner current decoupling control scheme with sliding mode control is proven to be better than that of a conventional PI controller. The simulation and experimental results confirm the feasibility and validity of the proposed scheme. The simulation results also showed that the proposed decoupling scheme can successfully control the active and reactive parts independently with the given active and reactive current reference components.

The advantages of using a three-level NPC VSC inverter are: it offer lower total current harmonic distortion; lower switching frequency and the minimum power transistor rated voltage and current capability requirements; no need for an isolation transformer; and a simplified $L$-type interface filter. These advantages make the suggested composite power circuit topology and the control strategy more suitable for high voltage and large current applications, especially in ERPBTSs.It is suggested that future works might focus on anti-islanding and overload protection since a large number of ERLPABTS instruments shares the same power-bus in the factory.

\section{Appendix}

Table A1. Power transistor specifications adopted for the three-phase NPC-VSC inverter.

\begin{tabular}{lll}
\hline Components & \multicolumn{1}{c}{ Part name/Manufacturer } & Rating values \\
\hline IGBT & SKM400GB128D/SEMIKRON & $1200 \mathrm{~V}-400 \mathrm{~A}$ \\
Fast DIODE & SKKD75F12/SEMIKRON & $1200 \mathrm{~V}-75 \mathrm{~A}$ \\
Capacitor & YDK & $450 \mathrm{~V}-5000 \mu \mathrm{F}$ \\
\hline
\end{tabular}

Table A2. Specifications adopted for the proposed ERLPABTS under discharging mode.

\begin{tabular}{|c|c|c|}
\hline Elements & Parameters & Values \\
\hline \multirow{2}{*}{ Power Battery Pack } & Battery terminal voltage $V_{\text {bat }}$ & $240 \mathrm{~V}$ \\
\hline & Battery type & Li-ion \\
\hline \multirow{3}{*}{ AC Power grid } & Grid voltage (line to line rms) $V_{\mathrm{g}}$ & $380 \mathrm{~V}$ \\
\hline & Line frequency $f_{\mathrm{n}}$ & $50 \mathrm{~Hz}$ \\
\hline & Grid impedance $L_{\mathrm{g}}$ & $1 \mathrm{mH}$ \\
\hline L filter & Converter side inductor $L$ & $1 \mathrm{mH}$ \\
\hline \multirow{4}{*}{ DC-DC Converter } & Nominal power & $175 \mathrm{~kW}$ \\
\hline & Inductor for boost chopping $L$ & $4 \mathrm{mH}$ \\
\hline & Switching frequency $f_{\mathrm{s}}$ & $5000 \mathrm{~Hz}$ \\
\hline & Dead time $t_{\mathrm{d}}$ & $2 \mathrm{us}$ \\
\hline \multirow{6}{*}{ DC-AC Converter } & Nominal power $P_{\mathrm{e}}$ & $175 \mathrm{~kW}$ \\
\hline & Two series DC-link capacitor $C_{\mathrm{dc}}$ & $16,000 \mathrm{uF}$ \\
\hline & Initial dc-link capacitor voltage $V_{\mathrm{c} 0}$ & $500 \mathrm{~V}$ \\
\hline & DC-link voltage reference $V_{\mathrm{dc} \text { ref }}$ & $900 \mathrm{~V}$ \\
\hline & IGBT switching frequency $f_{\text {inv }}$ & $2000 \mathrm{~Hz}$ \\
\hline & Dead time $t_{\mathrm{d}}$ & 2 us \\
\hline
\end{tabular}




\section{Acknowledgments}

This work was supported by the Fundamental Research Funds for the Central Universities of China (NO. ZYGX2012J095), and was also supported by a National Research Foundation of Korea (NRF) grant funded by the Korea government (MEST) (No.2013-009458).

\section{Conflicts of Interest}

The authors declare no conflict of interest.

\section{References}

1. Zhang, L.; Kang, W.; Jia, L.; Zhao, M.; Xu, R. Control of Bidirectional Current Source SVPWM Converter in the Power Accumulator Battery Testing System. In Proceedings of the Power and Energy Engineering Conference (APPEEC), 2010 Asia-Pacific, Chengdu, China, 28-31 March 2010; pp. 1-4.

2. Schweighofer, B.; Raab, K.M.; Brasseur, G. Modeling of high power automotive batteries by the use of an automated test system. IEEE Trans. Instrum. Meas. 2003, 52, 1087-1091.

3. Kobayashi, H.; Shikano, M.; Koike, S.; Sakaebe, H.; Tatsunii, K. Investigation of positive electrodes after cycle testing of high-power Li-ion battery cells: I. An approach to the power fading mechanism using XANES. J. Power Sources 2007, 174, 380-386.

4. Li, G.-C.; Wang, H.-Y. Study on Fuzzy Control in Power Battery Testing System. In Proceedings of the IEEE International Conference on Control and Automation (ICCA), Guangzhou, China, 30 May-1 June 2007; pp. 1110-1112.

5. Rahman, M.K.; Saito, Y. Investigation of positive electrodes after cycle testing of high-power Li-ion battery cells: III: An approach to the power fade mechanism using FT-IR-ATR. J. Power Sources 2007, 174, 889-894.

6. Saito, Y.; Rahman, M.K. Investigation of positive electrodes after cycle testing of high-power Li-ion battery cells IV: An approach to the power fading mechanism by depth profile analysis of electrodes using glow discharge optical emission spectroscopy. J. Power Sources 2007, 174, $877-882$.

7. Zhang, Z.Y.; Zhang, J. Intelligent Test System on the Power Battery of Hybrid Electric Vehicle. In Proceedings of the 2010 Second International Workshop on Education Technology and Computer Science (ETCS), Wuhan, China, 6-7 March 2010; pp. 635-638.

8. Uno, M.; Tanaka, K. Accelerated charge-discharge cycling test and cycle life prediction model for supercapacitors in alternative battery applications. IEEE Trans. Ind. Electron. 2012, 59, 4704-4712.

9. Bauman, J.; Kazerani, M. A comparative study of fuel-cell-battery, fuel-cell-ultracapacitor, and fuel-cell-battery-ultracapacitor vehicles. IEEE Trans. Veh. Technol. 2008, 57, 760-769.

10. Yan, X.W.; Du, C.L.; Li, H.M.; Zhang, L.X.; Wang, F. Application of Three-Phase Current Source Converter in Power Battery Testing System for Electric Vehicles. In Proceedings of the International Conference on Electrical Machines and Systems (ICEMS), Wuhan, China, 17-20 October 2008; pp. 4205-4209. 
11. Long, B.; Xian, Z.; Lim, S.T.; Chong, K.T. Design of energy recovery power battery pack testing system. Int. Rev. Electr. Eng. 2012, 7, 4572-4683.

12. Nabae, A.; Takahashi, I.; Akagi, H. A new neutral-point-clamped pwm inverter. IEEE Trans. Ind. Appl. 1981, 17, 518-523.

13. Rodriguez, J.; Lai, J.S.; Peng, F.Z. Multilevel inverters: A survey of topologies, controls, and applications. IEEE Trans. Ind. Electron. 2002, 49, 724-738.

14. Cengelci, E.; Sulistijo, S.U.; Woo, B.O.; Enjeti, P.; Teodorescu, R.; Blaabjerg, F. A new medium-voltage PWM inverter topology for adjustable-speed drives. IEEE Trans. Ind. Appl. 1999, 35, 628-637.

15. Oh, W.-S.; Han, S.-K.; Choi, S.-W.; Moon, G.-W. A three phase three-level PWM switched voltage source inverter with zero neutral point potential. J. Power Electron. 2005, 5, 224-232.

16. Ramirez, J.D.B.; Rivas, J.J.R.; Peralta-Sanchez, E. DSP-based simplified space-vector PWM for a three-level VSI with experimental validation. J. Power Electron. 2012, 12, 285-293.

17. Choi, U.-M.; Lee, K.-B. Neutral-point voltage balancing method for three-level inverter systems with a time-offset estimation scheme. J. Power Electron. 2013, 13, 243-249.

18. Mondal, S.K.; Bose, B.K.; Oleschuk, V.; Pinto, J.O.P. Space vector pulse width modulation of three-level inverter extending operation into overmodulation region. IEEE Trans. Power Electron. 2003, 18, 604-611.

19. Busquets-Monge, S.; Bordonau, J.; Boroyevich, D.; Somavilla, S. The nearest three virtual space vector PWM-A modulation for the comprehensive neutral-point balancing in the three-level NPC inverter. IEEE Power Electron. Lett. 2004, 2, 11-15.

20. Jiang, W.D.; Du, S.W.; Chang, L.C.; Zhang, Y.; Zhao, Q. Hybrid PWM strategy of SVPWM and VSVPWM for NPC three-level voltage-source inverter. IEEE Trans. Power Electron. 2010, 25, 2607-2619.

21. Verveckken, J.; Silva, F.; Barros, D.; Driesen, J. Direct power control of series converter of unified power-flow controller with three-level neutral point clamped converter. IEEE Trans. Power Deliv. 2012, 27, 1772-1782.

22. Zhang, Y.C.; Zhu, J.G.; Zhao, Z.M.; Xu, W.; Dorrell, D.G. An improved direct torque control for three-level inverter-fed induction motor sensorless drive. IEEE Trans. Power Electron. 2012, 27, $1502-1513$.

23. Mukherjee, S.; Poddar, G. Direct torque control of squirrel cage induction motor for optimum current ripple using three-level inverter. IET Power Electron. 2010, 3, 904-914.

24. Kocalmis, A.; Sunter, S. Simulation of a Space Vector PWM Controller for a Three-Level Voltage-Fed Inverter Motor Drive. In Proceedings of the 32nd Annual Conference on IEEE Industrial Electronics (IECON), Paris, France, 6-10 November 2006; pp. 1915-1920.

25. Long, B.; Vista IV, F.P.; Lee, D.J.; Chong, K.T. Minimum time current control of three-phase PWM rectifier with LCL filter interface. Int. Rev. Electr. Eng. 2012, 7, 5330-5340.

26. Jacobsen, E.; Lyons, R. The sliding DFT. IEEE Signal Process. Mag. 2003, 20, 74-80.

27. Gullvik, W.; Norum, L.; Nilsen, R. Active Damping of Resonance Oscillations in LCL-Filters Based on Virtual Flux and Virtual Resistor. In Proceedings of the 2007 European Conference on Power Electronics and Applications, Aalborg, Denmark, 2-5 September 2007; pp. 1-10. 
28. Veeranna, S.B.; Yaragatti, U.R.; Beig, A.R. Space vector-based synchronised bus-clamping pulse width modulation algorithms for three-level voltage source inverter in overmodulation region. IET Power Electron. 2012, 5, 493-500.

29. Gupta, A.K.; Khambadkone, A.M. A general space vector PWM algorithm for multilevel inverters, including operation in overmodulation range. IEEE Trans. Power Electron. 2007, 22, $517-526$.

(C) 2013 by the authors; licensee MDPI, Basel, Switzerland. This article is an open access article distributed under the terms and conditions of the Creative Commons Attribution license (http://creativecommons.org/licenses/by/3.0/). 